\title{
New screening of foreign direct investment (FDI) in Europe: a first step towards a new paradigm?
}

\author{
Jerónimo MAILLO*
}

\begin{abstract}
In March 2019, Regulation 2019/452, establishing a European framework for the screening of FDI in the Union, was finally adopted after a fast-track legislative procedure of only one year and a half. However, the cooperation mechanism therein designed will only apply from in October 2020. Although the Regulation clearly establishes the principle of non-discrimination between third countries, it is evident that one of the main triggers of the new mechanism has been the exponential increase in direct investments in Europe from emerging economies and especially from China. Does this new regulation represent a new era for FDI in Europe? What is the scope and impact of the Regulation on future investment relationships? Does the Regulation try to limit FDI in Europe? Has there been a political shift in the EU towards less liberalization of these investments? Is effective protection established against risks to public security, lack of reciprocity and / or eventual unfair competition? Is it a first step of a trend that announces new future steps in the same direction? This contribution tries to answer all these questions.
\end{abstract}

Keywords: Trade-Investments-FDI-Common Commercial Policy-Tradedefence-Public security\& public order-Unfair competition

\section{(A) INTRODUCTION}

On 13 September 2or7, the European Commission published its proposal for a European regulation for the screening of foreign direct investment (FDI) in the European Union. ${ }^{\mathrm{I}}$ In record time for such a new topic — just a year and a half—, in March 2org, Regulation 2org/452 was finally adopted, establishing a framework for the supervision of FDI in the Union. ${ }^{2}$ The Regulation entered into force twenty days after its publication in the Official Journal of the European Union but it will not be fully applicable until II October 2020, which in practice

¿ Article received on ${ }_{3 I}$ July 2020 , accepted on 26 October 2020 and published on ${ }_{3 I}$ December 2020

* Professor of Public International Law and International Relations, Jean Monnet Chair on EU Law, Coordinator of the Center for Competition Policy \& Market Regulation, Royal Institute of European Studies, Universidad CEU San Pablo, CEU Universities

r European Commission Proposal for a Regulation of the European Parliament and of the Council establishing a framework for screening of foreign direct investments into the European Union, $\underline{\mathrm{COM} / 20{ }^{2} / \mathrm{o}_{4} 87}$ final-20I7/o22/(COD).

2 OJ L79 I/I. 
means that the new mechanisms will not be operational until that date. ${ }^{3}$

The new regulation promotes greater European controls on direct investments from outside the European Union. Although the Regulation clearly establishes the principle of nondiscrimination between third countries ${ }^{4}$ and, therefore, is not aimed at investments from any specific country, it is evident that one of the main triggers of the new mechanism has been the exponential increase in direct investments in Europe from emerging economies and especially from China. ${ }^{5}$ A concern has arisen not only because of the amount of such investments but because of their objectives (strategic assets that could put public security at risk) and the fact that they are carried out in the absence of reciprocity and with possible unfair competition from the Chinese investors (public companies or other companies financed or / and supported - sometimes even remotely controlled - by the Chinese Government). Therefore, China is not the sole objective of the new regulation, nor will its investments be unjustifiably treated differently than those of other third countries, but, contextually, it is at the origin of the Regulation and, undoubtedly, its investments may be the main affected.

Does this new regulation represent a new era for FDI in Europe? What is the scope and impact of the Regulation on future investment relationships? Does the Regulation try to limit FDI in Europe? Has there been a political shift in the EU towards less liberalization of these investments? Is effective protection established against risks to public security, lack of reciprocity and / or eventual unfair competition? Is it a first step of a trend that announces new future steps in the same direction? We will try in this work to answer all these questions.

To achieve these objectives, we will begin by understanding the background and the context in which the new regulation is approved: where we come from, what was the political position and the regulatory framework on the control of FDI both at the European Union level and at the national level of the Member states, as well as which is the position and trends in other global actors and what are the determining factors derived from previous international commitments of the European Union. Understanding this context is essential to comprehend the possibilities that the European Union had and the step that the new regulation implies.

We will continue with an in-depth analysis of the new screening: the chosen legal basis —with its reasons and its limitations—, the objectives of the new regulation and its scope regarding issues such as: invokable grounds for control; what, to whom and how control will

3 Article 17 of the Regulation.

4 Article 3.2 of the Regulation: "Rules and procedures related to screening mechanisms [...] shall be transparent and not discriminate between third countries".

5 See, among others, M. Schaake, 'Comment of a Member of the European Parliament', in J. Bourgeois, (ed), EU Framework for Foreign Direct Investment Control, (Wolters Kluwer, 2020), at 99-ıо, or J. Bourgeois \& E. Malathouni, 'The EU regulation on Screening Foreign Direct Investment: Another Piece of the Puzzle', in the same book, I69-I9I, at I70: "The regulation comes largely as a response to the lack of reciprocity faced by EU investors abroad and mainly in China”. See also European Commission Staff Working Document on Foreign Direct Investment in the EU, Following up on the Commission Communication "Welcoming Foreign Direct Investment while Protecting Essential Interests" of I3 September 2017, SWD(2019) ro8 final, r3 march 2019, at 67. 
be exercised; who controls and to what extent. We will finish with a critical assessment and some conclusions.

\section{(B) BACKGROUND AND CONTEXT}

(I) The Starting Point: the EU in favor of Investment Liberalization, but not at Any Cost

FDI is beneficial for the economy of the European Union because it contributes to growth, innovation and employment $(6 \%$ of jobs in the $\mathrm{EU}$ are in companies controlled by foreign investors). They often involve new capital, technological development and knowledge, leading to increased competition, productivity and better inclusion in the global value chain of companies, while creating entry opportunities for them in other markets. ${ }^{6}$ For this reason, there has been an exponential increase in FDI globally: from I99o to 2017 , they have multiplied by 15 , going from 2 to $3^{0}$ trillion US dollars. ${ }^{7}$

For this reason, too, the $\mathrm{EU}$ has been one of the most open markets for $\mathrm{FDI}^{8}$, as recognized by the OECD, while other global actors (e.g. China) are much more restrictive. ${ }^{9}$ European Member States have even been making efforts to attract foreign capital and sometimes even competing with each other to attract it. And this open character of the EU regarding FDI is true both for the period before and after the Lisbon Treaty (2010).

In this sense, there have been clear efforts since the beginning and especially since the Maastricht Treaty (1992) with the adoption of the renewed chapter on the free movement of capital in the Treaty (current articles 63 et seq TFEU). It is highly significant that the general principle of liberalization of capital movements was raised to constitutional rank, both for intra-EU and extra-EU movements. ${ }^{\text {10 }}$ It is also revealing that, when the first significant complaints against FDI from sovereign wealth funds arose, the European Union, instead of choosing to promote a legally binding supervisory mechanism, advocated and negotiated greater transparency of such funds and a code of conduct."

6 Copenhagen Economics, The World in Europe. Global FDI Flows Towards Europe: Extra-European FDI Flows Towards Europe (March 20I8) at 9.

7 UNCTAD, World Investment Report 20I8: Investment and New Industrial Policies (United Nations, 20I8), at 188 , table 2.

8 In $20 I_{5}$, the EU received $5 \cdot 7$ trillion euros in FDI, compared to 5. I trillion in the US and only I.I trillion in China ( ${ } \cdot 5$ if Hong Kong is included). See Eurostat -News release 20o/20I8 and Booklet of the European Commission, Screening of Foreign Direct Investment - An EU Framework. This gap has narrowed somewhat in the followingyears, although it is still very relevant.

9 OECD, OECD International Direct Investment Statistics 2019 (OECD 2020 ).

ro See Article 63.I TFEU and below, in this same contribution, the analysis of EU Constitutional Limits to FDI.

" European Commission, Communication from the Commission: A Common European Approach to Sovereign Wealth Funds, COM (2008) II5 provisional (Feb. 27, 2008). See also J. Lundqvist, 'Screening Foreign Direct Investment in the European Union: Prospects for a "Multispeed"Framework?, European Union Law Working Papers, Stanford - Vienna Transatlantic Technology Law Forum, at Io. 
After the Lisbon Treaty, this spirit was maintained with the new Common Commercial Policy powers that already included FDI for almost a decade, without reinforced controls on FDI until very recently. ${ }^{12}$

Therefore, it seems clear that the EU has always advocated a progressive liberalization of investments, albeit with values and reciprocity. An EU that, after the new FDI powers conferred by the Lisbon Treaty, also seems strengthened and better positioned to promote this objective than its Member States. ${ }^{13}$

Isn't pushing for stronger controls on FDI inconsistent with this traditional position? Is there a political turn towards a greater restriction on FDI? And if so, how is this twist explained and what is its scope? To understand it, one must ask what has changed in recent years in the global FDI landscape and especiallyin the FDI that the EU receives.

Compared to previous periods in which FDI came mainly from other OECD members (USA, Canada, Switzerland, Japan), in recent years, more FDI has come from emerging economies such as Brazil, Russia and especially China. ${ }^{14}$ In some of these emerging markets, the role of the State is much stronger and more 'dirigiste', raising questions about the purposes of the investments and about the respect of a level playing field. On the one hand, this origin and characterization raises suspicions that the goals and priorities are not merely economic or just to gain a return on investment, but more of a strategic-political nature and, therefore, may affect more security or public order (control of information and sensitive data, infrastructures, technologies or critical supplies). ${ }^{15}$ These suspicions grow especially when the investor is a State Owned Enterprise (SOE), or at least the State influences, directly or indirectly, its decisions.

On the other hand, there is concern that the equality or level playing field is not respected. The direct financing of the State in public companies or the granting of public aid and privileged financing by the State to private companies, together with a lack of transparency in such aid, and the lack of reciprocity in the opening of internal markets in these countries, generates imbalances and unfair competition that does not seem acceptable, especially when some of these emerging markets have grown exponentially in recent years. Furthermore, neither the regulation of international trade nor the European internal regulatory framework were prepared to deal effectively with this unfair competition.

${ }^{12}$ European Commission, Towards a comprehensive European international investment policy, COM (2010) 343 final, July 2ого, at 2; and European Commission, Trade for all: Towards a more responsible trade and investment policy, $\underline{\mathrm{COM}\left(20 \mathrm{I}_{5}\right)} 497$ final, I $_{4}$ October 2015, at $5^{-6 .}$

ı3 M. Martín-Prat, 'The European Commission Proposal on FDI Screening', in Bourgeois supra n. 5, 95-98, at 97.

ז4 European Commission, supra n. 5, at 67.

${ }_{5}$ European Parliament, Proposal for a Union Act on the Screening of FDI in Strategic Sectors, B8-0302/2017, 26 April 2017 . 
These concerns are assimilated to those of other global actors ${ }^{16}$, but perhaps in Europe, being a particularly open market and with fewer mechanisms of supervision and control, they may be more pressing. ${ }^{17}$

With this breeding ground, it is not surprising that demands have grown progressively to equip the European Union with instruments that could effectively protect European interests against risks to public safety and face unfair competition.

As early as 2oı, the European Commission argued that liberalization had to be reciprocal and that it was essential to maintain a level playing field. ${ }^{8}$ However, these pronouncements were not yet accompanied by concrete proposals for new instruments to solve it. In 2oIr, in a letter to the President of the European Commission, two of its members (the then Commissioners Barnier -Single Market- and Tajani -Industry-) asked to open a debate to create a centralized European mechanism for controlling strategic investments. The initiative met with the opposition of the Commissioner of Commerce (De Gucht) and several Member States, so it did not succeed. ${ }^{9}$

After a peak of FDI in Europe in $2 \mathrm{O}_{5}$ and a wave of acquisitions of European companies by Chinese investors ${ }^{20}$, the years 2016 and especially 2017 opened a new phase of claims to act and this time led to successful concrete initiatives. ${ }^{21}$

In 2016 , Sigmar Gabriel, then Minister of Economy in Germany, warned that his country was sacrificing its companies on the altar of the free market without receiving adequate compensations from the Chinese government. ${ }^{22}$ In February 20I7, the governments of Germany, France and Italy sent a joint letter to the European Commission demanding to act. ${ }^{23}$ In May 20I7, in its reflection document "Harnessing Globalization", the European Commission echoed these concerns and insisted on the need to ensure a level playing field. ${ }^{24}$ In June 20I7, the European Council welcomed the Commission's initiative to explore an FDI control mechanism. ${ }^{25}$ In July 20I7, the German, French and Italian governments insisted on

I6 UNCTAD, supra n. 7.

${ }_{17}$ Lundqvist, supra n. II, at 3 .

18 European Commission, 'Towards ..., supra n. 12, at 4 .

I9 See Miller, 'EU Mulls Board to Review Foreign Investments', Wall St.J. (Mar. I/4, 20II), and Von ReppertBismarck, 'Analysis: Rising Foreign Investment Fuels Vetting Debate', (Reuters, 8 march 2orI).

${ }^{20} 37$ billion Chinese FDI in Europe in 2or6. See T. Hanemann \& M. Huotari, EU-China FDI: Working towards reciprocity in investment relations. A report by Rhodium Group (RHG) and the Mercator Institute for China Studies (MERICS, 2018).

${ }^{21}$ For a detailed analysis of FDI, see European Commission, supra n. 5 .

${ }_{22}$ J. Delcker, 'Sigmar Gabriel's Mission to Halt China's Investment Spree', POLITICO (Nov. I, 2016),

${ }^{23}$ Germany, France \& Italy, Proposals for Ensuring an Improved Level Playing Field in Trade and Investment (Feb. 2017).

${ }_{24} \operatorname{COM}(2017) 240$ of io May 2017.

${ }_{25}$ European Council, Conclusions, EUCO 8/17, June 22-23, 2017. 
their proposals with a more developed document. ${ }^{26}$ The Commission elaborated on its reflection document on how to take advantage of globalization in September ${ }^{27}$ and the same month adopted its proposal for a Regulation on FDI. ${ }^{28}$ In just a year and a half the proposal would end up being approved. ${ }^{29}$

The then President of the European Commission, Juncker, declared: "Europe must always defend its strategic interests and that is precisely what this new framework will help us to do. This is what I mean when I say that we are not naïve free traders. We need scrutiny over purchases by foreign companies that target Europe's strategic assets".$^{3^{\circ}}$ The declarations were now followed by concrete actions. The European FDI Control Regulation is one of them, one more piece of a puzzle under construction. ${ }^{3}$

Not being naive, even if you continue to believe and promote the liberalization of FDI, maintaining a policy of openness to investments but not at any cost, seem to be the keys to understanding the turn of the new European policy of which the Regulation under study is a key piece. And it does not seem that it will be a one-day flower because other initiatives confirm the same line of concern and action. ${ }^{2}$

\section{(2) Constitutional Limits in the EU to Controls on FDI}

It is important to understand what the framework prior to this regulation is and where the new instrument will be inserted. In particular, the capitals chapter in the TFEU was the main reference in European Law to understand the possibilities of action regarding FDI.

Article 63 TFEU establishes a general principle of freedom of movement of capital not only intra-EU but also extra-EU. A principle that was constitutionalized since Maastricht (more especially since the entry into force of this new chapter of capital in January 1994) and which also has direct effect by which it confers rights and imposes obligations not only on the States but also on individuals. ${ }^{33}$ Significantly, it is the only freedom that also extends to third States

${ }^{26}$ Policy Paper submitted by the French, Italian, and German governments to the European Commission, European Investment Policy: A Common Approach to Investment Control (July 28 , 2017).

${ }_{27}$ European Commission, A balanced and progressive trade policy to harness globalisation, Communication from the Commission, $\mathrm{COM}(2017) 492$ final.

${ }_{28} \mathrm{COM} / 2017 / 0_{4} 87$ final - 2017/0224(COD).

29 On the whole legislative procedure and especially the positions of the European Parliament along it, see A. Neergard, 'The Adoption of the Regulation Establishing a Framework for Screening of Foreign Direct Investments into the European Union', in Bourgeois, supra n. 5 , I5 I-I67.

$3^{\circ}$ European Commission, $\underline{I_{-}{ }_{1} 8_{-} 6467}$.

${ }^{3^{\mathrm{I}}} \quad$ Bourgeois \& Malathhouni, supra n. 5 , at 187 -I9o. For an analysis of this trend towards a more cautious view to FDI, see C. Esplugues Mota, El Control de las Inversiones Extranjeras Directas (Tirant lo Blanch, 2018 ) at $4^{2-52 .}$

$3^{2}$ See A French-German Manifesto for European Industrial Policy fit for the 2Ist Century (rg Feb 2org), altogether with Macron, Renewing Europe (March 2or9) and A. Kramp-Karrenbauer, Making Europe Right (March 2or9). On China, it is very revealing to see European Commission, EU-China-A strategic Outlook, JOIN (2019) 5 final.

33 There is direct effect of the liberalization principle also with regard to extra-EU movements (see 
and, in principle, on equal terms. However, there are exceptions to the free movement, and they are not the same for intra-EU as for extra-EU, thereby opening a possible differentiation of treatment: for extra-EU we may apply additional exceptions.

The principle of free movement applies to all types of capital movements, not only to portfolio investments but also to direct investments. This is evident when looking at the annex to Directive of 1988 that includes a section on such direct investments. ${ }^{34}$ In principle, these direct investments include real estate investments, greenfield investments (establishment of new companies, subsidiaries or branches) and brownfield (purchases of existing companies through mergers or acquisitions). ${ }^{35}$

It is also important to understand the exceptions applicable to this principle of free movement of capital:

First. Legitimate restrictions on free establishment for which, it should be noted, there is no liberalization with respect to third parties. $3^{6}$

We must distinguish 3 possible scenarios:

Scenario I: If the transaction is a mere corollary to a capital movement, art. 63 is applicable and, therefore, the transaction should not be examined under the freedom of establishment. ${ }^{37}$

Scenario 2: However, the former would not be the case if there is: a) an incorporation of a new company in accordance with national law (Greenfield investment) by investors from third countries; b) a merger with (or acquisition of) a company already established in the country (brownfield investment) by investors from third countries. In both, we would be before the right of establishment that is not liberalized for third States.

Scenario 3: What about other capital acquisitions in existing companies in that MS?

a) If there is only a passive investment (without interest or intention to influence the control and management of the company), it is a capital movement.

b) If, on the contrary, investments allow the investor to exert a 'real influence' on the company's decisions (“definite influence on a company's decisions”), it falls under freedom of establishment. ${ }^{3}$

Judgment of the Court (of I8 December 2007, C-1oi/o 5 , Skatteverket, ECLI:EU:C:2007:804, para. $3^{8}$ ), but it cannot be ruled out that, due to the different context, an exception can be accepted for extra-EU movements that would not have been accepted for intra-EU movements (see Judgment of the Court of 12 December 20o6, C-446/o4, Test Claimants in the FII Group Litigation, ECLI:EU:C:2006:774, para. 12I).

34 Annex I of Council Directive of $2 / 4$ Juneig88 (88/36I/CEE), OJ L $178 / 5$. The CJEU, in case Trummer (Judgment of the Court of 16 March 1999, C-222/97), ECLI:EU:C:I999:I43, confirmed that the nomenclature of said annex continues to have the same indicative value in order to check whether a transaction is a capital movement after the introduction of the new capital chapter.

35 CJEU, Judgment of the Court of II September 2014, C-47/12, Kronos, ECLI:EU:C:201/:2200, paras. $4^{0-42 .}$

$3^{6}$ See Article $6_{5.2}$ TFEU.

${ }_{37}$ This is, for instance, the case of real state investments: see CJEU, Judgment of the Court of 6 March 2or8, C-52/16 \& C-113/16, Segro, ECLI:EU:C:20I8:I57, paras. 54-55.

$3^{8}$ GJEU, Judgment of the Court of ${ }_{3} 3$ November 2012, C-35/II, Test Claimants (II), ECLI:EU:C:20I2:707, paras. 90-92. 
And when is there 'real influence'? It has to be decided in each specific case, since there is no clear test in the case-law. ${ }^{39}$ We know that a majority of capital is not necessary, but participation cannot be marginal or merely passive. Personally, I think that if there is control participation (veto in strategic decisions), it should be considered establishment. Therefore, any investment that implies 'decisive influence' in accordance with the European merger control regulation should be considered real influence. Below that threshold, it is more doubtful. It cannot be ruled out that, as rules for competition and freedom of establishment / foreign investment have different objectives, cases in which there would be no decisive influence according to the first may be cases of real influence according to the second; that is, even if you do not participate in the control of the company, you can exert a certain influence (although not decisive) on some management decisions, always beyond a mere passive investment.

Consequently, if we are in scenario 2 or 3 b), when falling under free establishment, there is no general principle of liberalization regarding extra-EU investments. Therefore, each Member State can establish its own rules regarding the access and exercise of this free establishment by non-community third parties in its territory. However, it is necessary to be aware that, once a company has been incorporated or created a subsidiary in accordance with the legislation of that Member State and as long as it meets the minimum requirements of that Member State to continue to be considered a company of that State, it will be equated to a national of that Member State and, therefore, may exercise the right of free establishment in the rest of the European Union without further limitations than those required to the rest of EU companies, that is, those justified by a general interest and proportionate. Given the divergences between Member States and the limited requirements demanded by some, an indirect route can be opened to channel this type of FDI without obstacles or, with much less.

On the other hand, if we are in a case of scenarios $\mathrm{s}$ or 3 a), the initial presumption is going to be investment liberalization, so there will be significant FDI possibilities for actors from third States in the EU. However, it is true that this principle of investment liberalization can be broken by applying certain exceptions provided for in the Treaty; exceptions, moreover, that are broader than those provided for intra-EU movements and that we will see below.

Second. Legitimate restrictions on non-EU capital movements, in particular on FDI from outside the EU.

a) Pre-existing restrictions. All restrictions on FDI, both national and European, that existed as of $3^{\text {I December }}$ I993, can be maintained, according to article 64.I TFEU. . $^{\circ}$ In this case, there is no need to invoke any justification based on general interest or to prove that the restriction is proportionate. Article 64.I allows to maintain the status quo, the already existing

39 S. Hindelang, The Free Movement of Capital and Foreign Direct Investment: The Scope of Protection in EU Law, OUP 20o9, [doi: ro.Io93/acprof:oso/9780I99572656.00I.00oI] at $8_{5}$.

$4^{\circ}$ In Bulgaria, Estonia and Hungary, the date is $3^{I}$ December I999. For Croatia, it is $3^{I}$ December 2002. 
restrictions. On the contrary, it must be understood that any new restriction (or extension of an existing one) would have to be duly justifiable under one of the exceptions provided.

Regarding pre-existing ones, the EU could adopt new liberalizations that affect both national and community restrictions, through the ordinary legislative procedure (art- 64.2 TFEU). This implies that qualified majority would suffice to liberalize. However, to establish new restrictions, unanimity would be necessary, in accordance with article 64.3 TFEU. This difference is very revealing of the spirit that presided over the adoption of the new capital chapter in the gos and in particular of the regime that was desired for FDI: the adoption of new liberalizations by the EU was clearly facilitated (majority voting) while raising new obstacles to back down in liberalization was very difficult (unanimity). A single State veto in the Council would block any backtracking or further restriction. In a Union of 28, with some States very interested in keeping their markets open to FDI, it made almost impossible to introduce new restrictions without justification: at the national level because art. 64. I prohibited them and at European level because the unanimity of all the Member States was almost impossible. The only imaginable case in which such unanimity would be relatively easy to achieve could be when a third country was denying the $\mathrm{EU}$ (all EU states) reasonable conditions of reciprocity in accessing its markets.

Furthermore, it must be borne in mind that: first, the reform of article 64 TFEU, being primary law, is very complicated and would also require unanimity after a rigid review process; second, despite the fact that 64.2 TFEU was applicable "without prejudice to the provisions of the other chapters of the Treaties", FDI did not enter the scope of the Common Commercial Policy until the reform of the Lisbon Treaty in 2009.

For all these reasons, it can be understood that this regime produced a weakening of the EU's negotiating position in order to achieve more openness and better conditions of access to third-country markets, especially in bilateral agreements, today prevailing given the global scenario of serious difficulties to advance at the multilateral level. Indeed, for a good connoisseur of the EU system, and in particular of this article 64 TFEU, the threat of introduction of new restrictions on FDI by either the EU or its Member States was not credible (unless they could be justified based on a general interest). The Lisbon Treaty may have changed this scenario by including FDI within the scope of the Common Commercial Policy and thus by opening up the possibility for the EU to introduce or promote new restrictions. The recent exercise of these new powers (through the new European FDI control regulation) could be interpreted as one more step to close this deficit. ${ }^{4}$

b) New restrictions justified by the general interest. The capital chap ter provides for other exceptions to the general principle of FDI freedom that would allow new restrictions to be introduced by Member States or the European Union, but only if they are justified on the basis

${ }^{4} \quad$ S. Schill, 'Foreign Direct Investment in the European Union: Rising Protectionism or Instrument for Further Investment Liberalization?', in Bourgeois, supra n. 5, 57-75. 
of a general interest and are proportionate. Thus, Article $6_{5}$ TFEU allows, both for intra-EU and extra-EU movements, that States establish new restrictions to, among others, "prevent infringements of national law and regulations, in particular in the field of taxation and the prudential supervision of financial institutions, or to lay down procedures for the declaration of capital movements for purposes of administrative or statistical information, or to take measures which are justified on grounds of public policy or public security”. Note that the list of justifications is merely exemplary as evidenced by the breadth of its first paragraph ("prevent infringements of national law and regulations"), by the fact that the list is preceded by "in particular" (that is, as an example), and that at the end of the list the conjunction "or" is used. Furthermore, in case of any doubt, the CJEU has said that, similar to what happens in other freedoms and regardless of the explicit exceptions, other public interests can be invoked. $4^{2}$ Thus, the possibility is opened for invoking any justification based on a general interest worthy of protection at European level and, in accordance with the provisions of article $6_{5.3}$ and the case law of the C.JEU, provided they are proportionate. In addition, it is necessary to be aware that such exceptions should be interpreted restrictively. 43

Article 66 TFEU also allows the Council, by a qualified majority, to adopt safeguard measures when extra-EU capital movements cause, or threaten to cause, serious difficulties for the functioning of the Economic and Monetary Union. In any case, these restrictions could be maintained for a maximum period of 6 months. To extend them further, it would be necessary to resort to the procedure of article 64.3 , which requires unanimity. Article 346 TFEU also creates an exception applicable to FDI in the defence and security sector.

Therefore, it is interesting to conclude that, regardless of the possibilities opened up by the new European regulation of FDI control, the Treaty does allow introducing new restrictions by the States (and in the case of Article 66 by the Union) if there is a justification based on a general interest and the restriction is proportionate.

However, these possibilities were far from solving the aforementioned deficit and the weakening of the European negotiating power to open foreign markets to European investment. There was still an imbalance as Europeans could only restrict on public interest grounds and with proportionate measures, or by unanimity of all Member States, while the possibilities of third States were greater, as they were not subject (and even less constitutionally) to the same conditions.

\section{(3) Divergences between Member States on FDI Control}

Within the EU, there are many divergences regarding controls on FDI. At the time of the

\footnotetext{
$4^{2}$ See, among others, CJEU, Judgment of the Court of 4 June 2oo2, C-367 $/ 98$, Commission v. Portugal, ECLI:EU:C:2002:326.

43 CJEU, Judgment of the Court of I/4 March 20oo, C-54/99, Scientology Church, ECLI:EU:C:20oo:I24, paras. I7-I8. It is not possible to invoke economic ends.
} 
proposed regulation, I2 MS had some type of supervisory mechanism (at the end of December

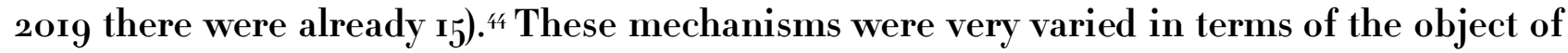
control and the design of the supervision system. Regarding the object, they varied in terms of activities (some only military or defense, others broader including also security or infrastructures, technologies or critical inputs) and the minimum shareholding thresholds to activate control. Regarding the design, some were prior authorization systems (prior notification and approval by the authority), others were ex post, or with a mix of both formulas. The divergences were not only economic but also geo-political, since the interests and dependence of these FDI were also very different. ${ }^{45}$ Furthermore, as LUNDQVIST rightly points out, it is also necessary to take into account the margin of autonomy that sub-state entities had in some Member States to negotiate directly with foreign investors..$^{6}$

For all these reasons, it is not surprising that opinions on the possibility of establishing a European FDI control mechanism were also very different. Before the European Commission proposal, France, Germany and Italy had already expressed their concern about the acquisition of strategic companies by non-European investors and the lack of reciprocity and fair competition (level playing field). ${ }^{47}$ Their proposals went far beyond what the European Commission ended up proposing and was finally adopted and which, as we will see later, does not directly contemplate neither the lack of reciprocity nor the unfair competition and level playing field concerns. On the contrary, for other Member States such as the Nordic countries, Ireland, the United Kingdom, Spain, Portugal and Greece, the proposals were perceived as protectionist. As if that were not enough, some other MS were concerned that the European Commission would begin to interfere on public security issues, which they considered to be a clearly national power. $4^{8}$

Both the lack of supervision and the divergent controls lead to a clearly unsatisfactory scenario for multiple reasons. There are more and more interconnections and externalities, especially within Europe given our Single Market and our deeper integration. In this context, an FDI can be a threat to the State that receives it, to a different MS than the one that receives

4f Germany, Austria, Denmark, Spain, Finland, France, Hungary, Italy, Latvia, Lithuania, the Netherlands, Poland, Portugal, the United Kingdom and Romania had notified control mechanisms to the European Commission as of December 2019 .

45 See, in this sense, the editorial of European Law Review, (2019) 44 ELRev, at. $3^{8}$.

$4^{6}$ Lundqvist, supra n. II, at 8: "All EU Member States are parties to the European Charter of Local SelfGovernment. This Charter recognizes a broad scope of rights for local governments to manage public affairs without federal oversight. Local governments have relied on this right to negotiate directly with foreign investors over investments in infrastructure”.

47 See above section B.I

$4^{8}$ F. Di Benedetto, ‘A European Committee on Foreign Investment?’, Columbia FDI Perspectives, (2017), no. 2I4. For more details on national positions, see G. Grieger (2018), European Parliamentary Research Serv., Briefing: EU Framework for FDI Screening, (20I8), at 6. 
it, to several MS or even to the entire Union. ${ }^{49}$ All this is even more evident in cases of projects of common interest with strong EU funding (eg Galileo navigation system, trans-European networks, or large EU research and innovation programs). Sufficient information exchange between MS and with the EU is lacking, leading to a lack of coordination of national systems, poor protection of national interests and even more so of Europeans.

In addition, it should also be noted that the supranationalization of FDI powers that occurred with the Lisbon Treaty was done without much debate, going largely unnoticed. It is not surprising, therefore, that the underlying divergences and controversies have been carried over to the implementation phase..$^{\circ}$

\section{(4) Strengthened Controls on FDI from Other Global Actors}

The main global actors have FDI supervision mechanisms, some of which have also been expanded and strengthened in recent years to face growing concern about the change in context.

Thus, in the US, research and control over FDI is carried out by CFIUS (Committee on Foreign Investment in the US) and has recently been reformed by FIRRMA (Foreign Investment Risk Review Modernization Act), which sought to modernize and strengthen the review mechanism for national security reasons. Again, the main reason was concerns about Chinese investments in the US..$^{5}$

In China, the system has also been reformed: it has gone from 3 lists (prohibited, restricted and promoted) to a principle of liberalization except for a negative list. In recent times, some restrictions have been removed from the negative list, but still many restrictions remain. ${ }^{5^{2}}$

According to studies by international organizations, professionals and scholars, this trend of establishing, strengthening or maintaining important controls on FDI is global. ${ }^{53}$

(5) Due Respect for the EU's International Commitments: WTO and Others

All the old and new instruments (such as those called to establish the new European Regulation) allow the Union and the Member States to adopt restrictive measures regarding

49 M. Martín-Prat, 'The European Commission Proposal on FDI Screening', in Bourgeois, supra n. 5, 95-98, at 97.

$5^{\circ} \quad$ S. Meunier, 'Integration by Stealth: How the European Union Gained Competence over Foreign Direct Investment, 55 J. COMMON MKT. STUD. (2017) 593, [doi: I0.IIII/jcms.I2528], especially at 606.

$5^{\mathrm{I}} \quad$ See P. Rose, 'FIRRMA and National Security', Ohio State Public Law Working Paper, (2018), no. 45², and J. Mendenhall \& R. Terney, ), 'CFIUS Review', in Bourgeois, supra n. 5, 135-147.

$5^{2}$ Bourgeois \& Malathoumi, supra n. 5 , at I73; Hanemann \& Huotari, supra n. 20, at I4. See also the annual European Business in China Position Papers of the European Chamber of Commerce in China.

53 Baker Mckenzie, Rising Scrutiny: Assessing The Global Foreign Investment Review Landscape, (2017), at $3^{2-66 ;}$ S. Thomsen \& F. Mistura (2017), Is Investment Protectionism On The Rise?: Evidence From The OECD FDI Regulatory Restrictiveness Index, 2017. 
foreign direct investment, for reasons of security or public order, provided that the international commitments that the EU and the States have assumed are also respected. Indeed, as the Preamble of the European Regulation itself will finally state:

"The implementation of this Regulation by the Union and the Member States should comply with the relevant requirements for the imposition of restrictive measures on grounds of security and public order in the WTO agreements, including, in particular, Article XIV(a) and Article XIV bis of the General Agreement on Trade in Services (I2) (GATS). It should also comply with Union law and be consistent with commitments made under other trade and investment agreements to which the Union or Member States are parties and trade and investment arrangements to which the Union or Member States are adherents". ${ }^{4}$

Article XIV (a) of the GATS establishes possibilities of exceptions for reasons of public morality and public order, provided they do not constitute arbitrary or unjustified discrimination. Public order requires that there be a serious threat to a fundamental interest of society.

Article XIVbis of the GATS establishes exceptions for military purposes or other emergencies in international relations. The exception seems quite restrictive (similar to Article 346 TFEU at intra-EU level).

In any case, before seeing if the exception is applicable, a preliminary step is to analyze whether there is a breach of any commitment made by the GATS given that there may be investments linked to free establishment. Among those commitments are those of the Most Favored Nation clause (II), Market Access (XVI) or National Treatment (XVII). If there is a risk of violating any of these commitments, it is when exceptions could come into play. If these commitments are not breached, the restrictions are valid without the need to apply the exceptions. The necessary respect for these limits must always be taken into account when designing and drafting any new FDI control mechanism and, therefore, they could also have had an influence on how the European Regulation was designed..$^{55}$

\section{(C) THE NEW EU SCREENING FRAMEWORK}

\section{(I) Powers of the European Union and Legal Basis}

The new European Regulation has chosen Article 207.I TFEU as a legal basis, which, after the reform of the Lisbon Treaty, includes FDI in the Common Commercial Policy, an exclusive competence of the European Union. Opinion $2 /{ }_{5} 5$ of the CJEU cl early established that this new EU competence includes both the liberalization of pre-establishment investments (access,

$54 \quad$ Preamble, paras. 3 and 35 .

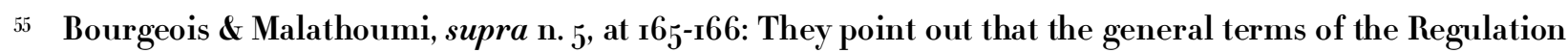
prevent the incompatibility with the mentioned provisions of the WTO. The responses and restrictions imposed are ultimately national measures. What if these measures restricted investments? The authors consider that the governmental control factor and ownership structure could be controversial. The rest of the factors enshrined in article 4.2 do not seem to pose problems. 
openness) and the protection of post-establishment investments (non-discrimination, fair and equitable), since it aims to "promote, facilitate or regulate trade" with third States and may have direct and immediate effects on this international trade. ${ }^{6}$ This may include respecting international commitments made by the EU such as environmental, social, nondiscrimination or other limits to state discretion to ensure that restrictions are not disguised, unjustified or disproportionate. ${ }^{57}$

However, it does not extend to portfolio investments and alternative dispute resolution mechanisms..$^{8}$ For this reason, the signing of trade agreements that include these elements would require either a mixed agreement, or two separate agreements for the different blocks, ${ }^{59}$ or only an EU agreement but authorized by the Council on a proposal by the Commission. ${ }^{60}$

Article 207 TFEU was not, however, the only possible basis that could be considered. Also, article $6_{4}$ TFEU, within the framework of the free movement of capital, would have allowed the adoption of a regulation on FDI control. The option for Article 207 TFEU is controversial.

Some authors consider that, as the Regulation is drafted, the legal basis is correct, ${ }^{6 \mathrm{r}}$ although they do not fail to point out its limitations, especially for the future. ${ }^{{ }_{2}}$ NEERGARD, for example, recognizes that article 64 TFEU could also have been a good legal basis, but states that, given the "without prejudice to the provisions of the other chapters of the Treaties..." in the drafting of article 64 TFEU, Article 207 TFEU is more correct.

However, other authors say that the use of 207 TFEU as a legal basis is, at least debatable, fragile and questionable, perhaps prompted by the European Commission's attempt to seize the opportunity to consolidate this power after Lisbon and that Article 64 TFEU would have been more appropriate. ${ }^{6}$ Furthermore, they warn that, although with the current wording, the legal basis may be acceptable by continuing to leave in the Member States the final decision on whether security and public order are affected and how to intervene, it would not allow the

$5^{6}$ CJEU, Opinion 2/I5 I6 may 2oI7, Singapore Free tarde agreement, ECLI:EU:C:2017:376, paras. 78 -IIo.

57 M. Cremona, 'Regulating FDI in the EU Legal Framework', in Bourgeois, supra n. 5, 3'-55, at 53 .

$5^{8}$ CJEU, Opinion of the Court of 16 May 2or7, 2/ı5, ECLI:EU:C:2017:376, paras. 238, 243 and 293.

59 This is what happened with the Free Trade Agreement with Singapore.

6o CJEU, Judgment of the Court of 5 December 2oI7, C-6oo/ı_, Germanyv. Council, ECLI:EU:C:20I7:935, para. 68.

6r Cremona, supra n. 57 , at 53-54 or Neergard, supra n. 29, at $16_{5}$ and 166 .

${ }_{62}$ For instance, Cremona, supra n. 57 , at $53-54$ considers that the 207 TFEU is correct because the Regulation does not establish a new European regulatorymechanism and national competence is preserved (it is the MS who decide whether to control it or not, and what type of control to exercise, always with certain guarantees at European level; the list of factors to keep in mind is not exhaustive). But, if they wanted to adopt future rules replacing national control by a European one, she seems to consider that the most correct legal basis should be Article 64TFEU.

${ }_{3}$ R. Bismuth, 'ReadingBetween the Lines of the EU Regulation Establishinga Frameworkfor ScreeningFDI into the Union, in Bourgeois, supra n. 5, I03-II4, especially Io6-Io8 and III-II2. 
adoption of a European control instrument that replace the nationals. ${ }^{6}$ If further steps had to be taken to create that European mechanism, if the Regulation was seen as just a first step, it is highly doubtful whether article 207 TFEU is an adequate basis or that another legal basis can even be found to transfer decisions on security and public order at a centralized European level. ${ }^{6}$ In fact, national security is, according to Articles 4.2 TEU and 346 TFEU, an exclusive national competence and the European Commission itself recognizes that a single European instrument would be a very difficult option to articulate due to exclusive national competences on national security. ${ }^{66}$

We must not forget the different decision-making procedures that these legal bases imply. Article 207.2 TFEU indicates that the ordinary legislative procedure (therefore with a qualified majority in the Council) will be used. Article 64.2 TFEU establishes the same procedure, but only for measures that imply progress in liberalization, while for measures that imply a backward step in liberalization, Article 64.3 TFEU establishes a special legislative procedure, with a decision of the Council by unanimity, after consulting the European Parliament. Given that greater controls on FDI can be understood as a step backwards in liberalization, if Article 64 were used, resort to the procedure of paragraph 3 (unanimity) would be required. Thus, the choice of legal basis is, in this case, very relevant. By using 207 TFEU, the European Parliament was given a greater role (co-decision) and the negotiations occur under the shadow of the vote and not of the veto (qualified majority instead of unanimity). This difference could have influenced the choice of legal basis of the European Commission.

In conclusion, in its current wording, Article 207 TFEU seems to be acceptable and its legality is not debatable. It has advantages and limitations. The greatest advantage is that its negotiation and approval was carried out by the ordinary legislative procedure with qualified majority in the Council. The main disadvantages may be: first, that it can only be used for FDI and not for portfolio investments, therefore control is fragmented according to the type of investment and a gap can be generated in the system; second, it would not allow subsequent reforms to centralize control of FDI into a single European instrument. The fact that national security is an exclusive competence of the Member States would prevent this and,

${ }_{64}$ Bismuth, supra n. 62, at 112.

${ }_{6}$ Although public security is a national competence, the EU can put certain limits to its use as evidenced by the European control of public security exceptions in the framework of the freedoms of the Internal Market. It should also be explored whether, in addition to the concept of national security, there is a European security concept that could justify EU interventions.

66 See the Preamble of the Regulation, para. 7 and European Commission, supra n. 5 . According to Bismuth, supra n. 62, at II2: Article 207 TFEU (taking into account Opinion 2/I5, supra n. 55, especially at para. IoI), does not affect the right of MS to adopt justified measures for the protection of national security or public order under 65.I.b). The only thing that allows is to introduce this exception, to be exercised by the MS, in EU investment agreements. Against, R. Vidal Puig, 'The Scope of the New Exclusive Competence of the European Union with regard to Foreign Direct Investment', 40 Legal Issues of Economic Integration (2013), , 33 , especially at I57-I6o. 
furthermore, it seems to have greatly conditioned the very design and scope of the proposed and finally approved European framework.

(2) Objectives and Scope

\section{(a) A new balance between liberalization and control}

To understand the new Regulation, we must start by reaffirming that the European Union will try to maintain an open and attractive system for FDI. As the then Vice-President of the European Commission declared at the time of the launch of the proposed Regulation "the EU is and will remain one of the most open investments regimes in the world. FDI is an important source of growth, jobs and innovation)" ${ }^{6}{ }_{7}$ This opening and promotion of FDI liberalization is, and will continue to be, in the European $\mathrm{DNA}^{68}$ and the Regulation should not be interpreted as protectionism nor should protectionist use be made of it. ${ }^{69}$

However, the Regulation encourages the establishment and application of limits to this liberalization when they are justified by putting public security and order at risk. It is, therefore, one of the actions that the European Union promotes after acknowledging that it has been somewhat naive, with respect to these FDI and that it has lacked sufficient controls.

At the same time, these new and reinforced controls seek to increase the EU's international negotiating power with third countries in investment matters by not assuming that the European doors will always be open without conditions. From this point of view, the Regulation could be seen as an instrument to promote the liberalization of investments at the international level rather than as a protectionist measure to favor European industry. ${ }^{7^{\circ}}$ The fact that the Regulation is limited to promoting controls when there are risks to security and public order and has not directly and prevalently dealt with issues related to lack of reciprocity and unfair competition, may point in the same direction, reaffirming the pro opening and pro liberalization background position of the EU in the new context.

The Regulation must therefore be understood as a new balance between several general interests: on the one hand, the positive effects of investment liberalization and the attraction of FDI in Europe, which are still very present; and, on the other hand, the need for greater controls, to set justified limits and to provide more effective instruments to protect against possible abuses and damages to national and European interests. The Regulation is the result of a new balance between liberalization and control, as required by a new context.

${ }_{67}$ European Commission, Press release, I4 september 20I7. See as well European Commission, Reflection Paper on Harnessing Globalisation, $\mathrm{COM(20I7)240}$ of Io May 20I7, at 15.

68 Bismuth, supra n. $6_{3}$, at 105 .

69 Schaake, supra n. 5 , at IoI.

$7^{\circ}$ Schill, supra n. $4 \mathrm{I}$. 


\section{(b) Improved coordination and information at EU level when there is a risk to security or public order}

A mechanism for information exchange and cooperation is established among the Member States, and the Member States with the European Commission, regarding FDI that may affect security and public order. All Member States must participate — it is binding — whether or not they have a national control mechanism, although the degree of participation can be very diverse.

The mechanism can be initiated both in the event that the State receiving the investment has a national control for FDI and this control is activated (Article 6), and even when this is not the case if another Member State or the Commission considers that said FDI may affect security or public order, or has relevant information in relation to said FDI (Article 7). Note that it does not depend on whether the Member State has a control mechanism, but whether it is activated in the specific case.

In the first case, the recipient Member State shall automatically communicate to the Commission and to the other Member States at least all the information on the FDI mentioned in Article 9.2 of the Regulation. In the second case, the other affected Member State or the Commission may justifiably request the information from the recipient State (Article 7·5).

The recipient Member State may request the information provided in article 9.2 from the foreign investor and the investor will be obliged to provide it without und ue delay (article 9.4). Thus, it may be creating a direct obligation on investors, at least in cases where it does not exist in the relevant national law. The Regulations do not foresee sanctions in case of breach of this duty. It would be advisable to provide them in national law to make this obligation more effective. In fact, we might think that such an obligation is imposed on the Member State by the duty of loyal cooperation and the principle of effectiveness of EU law, as set out in Article $4 \cdot 3$ TEU.

In addition, the European Commission is empowered to issue non-binding opinions in two cases: (a) when it affects a program or project of interest to the EU (European funding, or programs covered by European Law, on infrastructures, technologies or critical supplies) (article 8.I); (b) when the Commission considers that public order and security maybe affected in more than one State of the Union or has relevant information in relation to said FDI (articles 6.3 and article 7.2). The Commission will be obliged to issue such an opinion when at least a third of the Member States consider that an FDI may affect their security or public order (Article 6.3 and 7.2); and the recipient Member State "shall give due consideration to the comments of the other Member States referred to in paragraph 2 and to the opinion of the Commission" (Articles 6.9 and 7.7).

Furthermore, if it is a Commission's opinion on a project or program of European interest as referred to in the Annex, ${ }^{71}$ the recipient Member State "shall take utmost account of the

\footnotetext{
${ }^{7}$ See Article 8.3 and the list of the Annex of the Regulation: European GNSS programs (Galileo and EGNOS),
} 
Commission's opinion and provide an explanation to the Commission if its opinion is not followed". It seems clear that the Commission's opinion is not formally binding, ${ }^{7^{2}}$ but also that it will be difficult for the State to go against it and that, in many cases, it will be followed.

The list in the annex is exhaustive. Article 8.3 initially seems to use an open formulation when it states that these programs include "those projects and programmes which involve a substantial amount or a significant share of Union funding, or which are covered by Union law regarding critical infrastructure, critical technologies or critical inputs which are essential for security or public order". But then it concludes stating that "The list of projects or programmes of Union interest is set out in the Annex." The European Parliament tried that the list of the Annex had no exhaustive character but it was not accepted. ${ }^{73}$ The objectives of these mechanisms seem to be:

- first, to increase the awareness of the Member States about the risks of some FDI not only for them but for other Member States and the European Union as a whole. Therefore, it is requested to assess the interconnection and externalities in other Member States, as well as the European dimension of public security;

- second, to generate a collective management of these risks and a response that, even if it is national, is taken after having listened to the other affected parties and having taken into account their concerns, observations or opinions;

- third, the European Commission is not conferred a formal veto power, but it is granted a significant influence on the final decision of the recipient State (soft power), especially when the FDI affects a program or project of European interest;

- fourth, increase the flow of information on FDI in Europe and create a forum for its discussion and, therefore, to assess possible future developments in the management of these FDI and its control mechanisms;

- fifth, generate a dynamic of greater national controls, impose a minimum framework for them and promote more soft harmonization of these national controls through collective management and best practices, without prejudice to respect for national powers; and

- sixth, take advantage of synergies. It would allow sharing intelligence among the different Member States, which could be especially interesting for countries that do not have it or where it is scarce. ${ }^{74}$

Copernicus, Horizon 2020, trans-European transport, energy and telecommunications networks, European Program for Industrial Development in the field of Defense and Permanent Structured Cooperation (CEP), as well as the subsequent modifications adopted by the Commission in accordance with article 8.4 and I6 of the Regulation.

$7^{2}$ Preamble of the Regulation, paras. I6 y 17 .

$73 \quad$ Neergard, supra n. 29, at $\mathrm{I}_{5} 8$.

$74 \quad \operatorname{ELRev}(2019)$, editorial, supra n. 45 , at 138 . 
(c) A common framework for national control mechanisms

\section{(i) Just a common framework? Power and soft harmonization}

A single European mechanism is not created and therefore veto powers are not directly conferred on the European Commission. Although the European Commission does not have a de jure veto to FDI, nevertheless it receives notifications, it can request information and issue opinions that shall be duly taken into account, in general, and, in some cases, into "utmost account", in addition to request from Member States an explanation to the Commission if its opinion is not followed. ${ }^{75}$ The European Commission thus gains a considerable soft power, although the responsibility ultimately lies with the Member States, which are the ones who formally take the decision. ${ }^{6}$ The opinions of the European Commission are not challengeable under an annulment action of article ${ }_{2} 6_{3}$ TFEU as they do not produce legal effects on third parties, and, where appropriate, they would not generate liability either, since the final decision will always be imputable to the Member State.

The Regulation also does not oblige, at least formally, Member States to adopt a mechanism at the national level. $\pi$ On the contrary, it allows MS to maintain or / and reform existing ones or adopt new mechanisms where they do not exist. Although it is not expressly mentioned that existing ones can be eliminated, it must be understood that this possibility is not excluded, given the great margin of action given to the States. In any case, it is evident that the Regulation points in another direction: far from promoting the elimination of existing ones, it implicitly encourages the adaptation (and reinforcement) of existing ones, as well as the creation of new ones where they do not exist..$^{8^{8}}$

In this regard, it should be remembered that: Article 5.I establishes that, even when a Member State does not have such a control mechanism, it will have the obligation to send an annual report to the European Commission on FDI in its territory based on the available information; Article 6, that Member States can issue observations and the European Commission an opinion and communicate them to the Member State where the FDI takes place if they consider that it involves a risk to security and public order, and this MemberState should duly take them into account; and Article 8 enables the Commission to adoptan opinion, if programs of European interest are affected, which the Member State must take into utmost account, providing the latter with an explanation if it does not follow it.

75 Articles 6 and 8 of the Regulation.

$7^{6}$ Bismuth, supra n. 63, at Io9-II, or N. Lavranos, 'Summary of the Discussion of the Final panel on the EU's

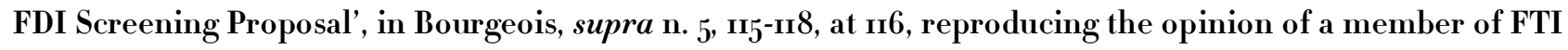
Consulting.

77 Duringthenegotiation, therewas much insistence by the Council on this point and on the fact that security and public order is an exclusive national competence: see Neergard, supra $\mathrm{n}$. 29, at 54 and the quotation of the reforms and adjustments required to article $\mathrm{I}$ and to paragraphs $3,4,8$ and $\mathrm{I} 7$ of the Preamble in order to insist on this point.

${ }_{7}^{8}$ In this same line, Bismuth, supra n. 63 , at ıo8-ıog. 
For all these actions, it would be better to have a legal basis in national law that enables and facilitates national action. This implicitly will lead many Member States to establish a national control mechanism (or a more comprehensive one). ${ }^{79}$

Furthermore, the Regulation requires to adjust existing and new national controls to a minimum common framework with conditions of transparency, non-discrimination between third countries, grounds for action, procedure, deadlines and appeals. ${ }^{80}$

In any case, it is only a minimal common framework. The Regulation leaves the final decision on FDI in the specific case to the State or States that are exercising supervision: it is them who decide whether or not to control the specific FDI, whether to raise objections or not, whether to restrict it or not. It is also them who will decide if they design an ex-ante, ex-post control or if there is no national control mechanism. Member States choose. The Regulationalso does not establish what measures to adopt, if any, to solve the threat to public order and security. Thus, the mechanisms provided for in the Regulation are called to fulfil a complementary function to that of national mechanisms. It seeks to help Member States and the European Commission to collectively assess potential cross-border or European threats to security and public order.

\section{(ii) The grounds for control}

Just public order and security? The Regulation refers only to intervention on grounds of public order and security, indicating a non-exhaustive list of factors that can be taken into account by the Member States.

Does this mean that Member States cannot limit FDI for reasons other than public order and security? Some authors seem to suggest that the answer would be yes and that the Member States could not invoke other reasons and, even less, economic reasons to control and /or block an investment. ${ }^{8}$ This conclusion could find support on the fact that FDI is now part of the Common Commercial Policy and as such the exclusive competence of the European Union. If the Regulation has not authorized limitations for reasons other than public order and security, this door has been closed for now. The issue may be controversial: first, because the chapters on capital movement and establishment (and the CJEU's interpretation of them) clearly admit other general interests as justifications, although never purely economic ends; second, because the Regulation at no time expressly excludes other reasons, although it must be recognized that during the negotiation other possible grounds such as lack of reciprocity and unfair competition were discussed and were not included (at least not as main grounds) in the final text; third, because it could be understood that the Regulation self-restrains to

79 Article 2.4 of the regulation defines 'screening mechanism' as "an instrument of general application, such as a law or regulation, and accompanying administrative requirements, implementing rules or guidelines, setting out the terms, conditions and procedures to assess, investigate, authorise, condition, prohibit or unwind foreign direct investments on grounds of security or public order;"

8o Seebelow section (c) (v).

${ }^{8}$ I Bourgeois \& Malathouni, supra n. 5 at 178 . 
establishing that the procedures set forth therein must be applied to cases in which there may be a threat to public order and security, and does not regulate other matters that must be governed by the other applicable European and national rules; Fourth, because it must be borne in mind that public order and security is a broad concept that is not defined in the Regulations and that can be detailed and must be applied by each State, who must establish the reasons for control (article 3.2); furthermore, the list of possible factors to take into account is a non-exhaustive list (article 4); fifth, because article 4.2 a) does refer to a factor linked to possible unfair competition, ${ }^{8_{2}}$ without excluding others; Sixth, because although it is not possible to resort to purely economic ends, public security can have an economic aspect economic public security - that has been recognized by the CJEU as a possible justification for restrictive measures. ${ }^{8_{3}}$

What is the meaning of public order and security in comparative law? The terms used in FDI Comparative Law present some variations, but not very substantial: in the USA and the recent FIRRMA the term is 'national security', as in the Canada Investment Act; in Australia, a broader concept is chosen: 'national interest'; in other jurisdictions the expression 'essential security interests' is preferred..$^{84}$

Regarding the content and the approach to these concepts, in some jurisdictions general guidance are offered, while others relied on a case-by-case analysis.

In some European Member States, reference is made only to the defence sector, while in others, different public interests are alluded to. ${ }^{8_{5}}$ The European Union has chosen in the Regulation to refer to public security and public order, including guidelines on its content and scope in the Regulation itself, and alluding to possible factors to be taken into account without being an exhaustive list. In the MEMO that accompanied the launch of the Regulation, it is stated that purely economic goals are not included.

What about the factors and sectors affected? The Regulation provides a non-exhaustive list of factors that can be taken into account by States to assess these threats. It is a mere orientated guide, neither mandatory nor exhaustive. It therefore offers very limited legal certainty: for investors -and to attract investment- more precision would have been desirable ${ }^{86}$

$8_{2}$ Article 4.2 a) indicates a possible factor to consider: "whether the foreign investor is directly or indirectly controlled by the government, including state bodies or armed forces, of a third country, including through ownership structure or significant funding;".

${ }_{3}$ Indeed, the CJEU has accepted it in multiple cases in the field of internal market freedoms, such as in Judgment of the Court of Io July I984, C-72/83, Campus Oil, ECLI:EU:C:I984:256, or Judgment of the Court of i3 May 2oo3, C-463/oo, Commission v. Spain (golden shares), ECLI:EU:C:2003:272.

84 For a more detailed analysis, see F. Wehrlé \&. Pohl, 'Investment Policies Related to National Security: A Survey of Country Practices', OECD Working Papers on International Investment, 2or6/o2, OECD Publishing, Paris.

$8_{5}$ European Commission, Staff Working Document accompanying the Regulation proposal, $\underline{\text { SWD (20I7) } 297}$ final, at 8 .

86 See, for instance, the comments by a representative of Goodyear in Lavranos, supra n. 76, at II5. 
It is interesting to note that there was a consensus among the three EU Institutions on the non-exhaustive nature of the list, ${ }^{8}{ }_{7}$ but there was a great discussion on what to include: the European Parliament was in favour of a longer and more detailed list, and even to make some of the factors mandatory, while the Council advocated a shorter and less detailed list. ${ }^{88}$

It is necessary to take into account, on the one hand, the articles of the Regulation, in particular Article 4, and, on the other hand, also the Preamble, in its sections II to I4. They differ slightly, although both have a similar status as they are non-binding and both are revealing of the main sectors that may be affected. Article 4.I of the Regulation says that the potential effects of FDI may be taken into account, among others in:

“a) critical infrastructure, whether physical or virtual, including energy, transport, water, health, communications, media, data processing or storage, aerospace, defence, electoral or financial infrastructure, and sensitive facilities, as well as land and real estate crucial for the use of such infrastructure;

b) critical technologies and dual use items as defined in point 1 of Article 2 of Council Regulation (EC) No $4^{2} 8 / 2009$ ( ${ }_{5}$ ), including artificial intelligence, robotics, semiconductors, cybersecurity, aerospace, defence, energy storage, quantum and nuclear technologies as well as nanotechnologies and biotechnologies;

c) supply of critical inputs, including energy or raw materials, as well as food security;

d) access to sensitive information, including personal data, or the ability to control such information; or

e) the freedom and pluralism of the media".

Additionally, Article 4.2 of the Regulation also mentions, among the factors that could be taken into account:

"a) whether the foreign investor is directly or indirectly controlled by the government, including state bodies or armed forces, of a third country, including through ownership structure or significant funding;

b) whether the foreign investor has already been involved in activities affecting security or public order in a Member State; or

c) whether there is a serious risk that the foreign investor engages in illegal or criminal activities."

The Preamble completes what is established in article 4 . For example, when saying that the Member States and the Commission must also be able to take into account "the context and circumstances of the foreign direct investment", and in relation to the point 4.2 a) of the Regulation, not only "in particular whether a foreign investor is controlled directly or indirectly, for example through significant funding, including subsidies, by the government of a third country" but also if it "is pursuing State-led outward projects or programmes".

It is interesting to note that a comparison between the material scope and the factors to be assessed in US regulations (CFIUS, after FIRRMA) and the European Regulation reveals their similarities. Beyond slight differences, both refer to practically the same sectors and factors. ${ }^{{ }^{8}}$

${ }_{7}$ Preamble of the Regulation, para. II.

88 Neergard, supra n. 29, at $\mathbf{I 5 5}^{-\mathbf{I} 5}$. The European Parliament wanted to include other factors such as reciprocity, human rights, labor standards and intellectual property, but they were not accepted.

${ }_{9} \quad$ For a detailed comparison, see Bourgeois \& Malathouni, supra n.5, at I8I-I82. 
There is an almost total coincidence in the underlying concerns of both regulations, something that can be very useful due to the more extensive experience in the application of the US regulations.

The listing also confirms that the concept of security and public order that is being targeted goes far beyond strictly the defence sector. Undoubtedly, it extends to other aspects of strategic security in today's societies such as data, information, technologies, key services for citizens, as well as critical infrastructures and supplies. From this perspective, it can be clearly concluded that it covers areas that have entered into previous CJEU case-law as 'economic' public security (guarantees of access, use and / or supply of services and critical supplies) and other public interests (guarantees for electoral processes, for the protection of personal data or media pluralism)..$^{\circ}$

In any case, the list is neither obligatory for the Member States (although not taking it into due account may require explanations from the affected Member State, especially if it diverges from the opinion of the European Commission) nor does it closes the list of sectors that could be affected and the factors that can be assessed. Let us remember that the list is not exhaustive and that, furthermore, it is ultimately a national competence, so Member States have the last word also on this matter. In addition, the examination will be done on a case-bycase basis, taking into account all the specific circumstances. Some of them can be very important such as: the intensity of the investment and the degree of influence in the recipient company; if the risk exists by the mere access to the information or if control over the company is acquired; or the degree of 'critical' intensity of the investment target.

\section{(iii) The controlled subject: Foreign investor}

In accordance with article 2 in its paragraphs 2 and 6 , a foreign investor is meant to be any natural person from a third country or company from a third country (that is, the one incorporated under the laws of a third country), who makes an FDI.

And what happens if a third-country company establishes itself in a Member State where a national mechanism for controlling foreign investment has not been created (for example, creating a subsidiary) and then, from this subsidiary, makes a direct investment in another Member State that does have FDI control? Should we consider that investment as an investment of an EU company and therefore not an FDI? On the contrary, should we consider it as an FDI and apply the new European Regulation to it?

In principle, as a general rule, it will be considered an intra-community investment. However, the Regulation has echoed the risk that this type of scenario poses to avoid the control of FDI: in article 3.6 of the Regulation, it is stated that "the Member States that have control mechanisms will maintain, modify or adopt the measures necessary to determine and avoid circumvention of the control mechanisms and control decisions". It should be borne in

9o Following the same line, ELRev (20I9) editorial, supra n. 45 , at ${ }_{13}^{8 .}$ 
mind that, in such situations, the subsidiary State, even if it does not have national control of FDI, may receive observations from other Member States and opinions from the Commission if there is a security risk in any Member State. Furthermore, we might think that Article 3.6 of the Regulation enables the Member State in which the subsidiary invests to consider the new investment as FDI with a view to avoiding circumvention of FDI control. ${ }^{\text {r }}$

The Preamble to the Regulation, in its section ı, clarifies that such measures should cover investments made within the Union "by means of artificial arrangements that do not reflect economic reality and circumvent the screening mechanisms and screening decisions, where the investor is ultimately owned or controlled by a natural person or an undertaking of a third country". It seems therefore that the goal is to block the practice of creating "Special-Purpose Entities" (SPEs), or letterbox companies, and that it could not be used in other cases in which European companies owned by investors from third States carry out genuine activities in the Member State where the investment comes from. ${ }^{9^{2}}$

Does all this mean that the foreign investor's position has been harmed by the adoption of the Regulation? Although it is true that the most important impact is that these FDI can be subjected to more and more reinforced controls, it is also possible that there will be some positive aspects for the foreign investor. Some FDI that were previously outside the scope of EU law and therefore did not benefit from its guarantees (for example, those associated with free establishment that does not extend to extra-EU relations), are now clearly applicable as all FDI are within the scope of the new Regulation and therefore of EU law. This implies that the guarantees of the Charter of Fundamental Rights of the European Union (CFREU) must be respected in addition to the rest of the limits and the common framework established in the Regulation. ${ }^{93}$

\section{(iv) The object of control}

Foreign direct investment. The Regulation is limited to FDI only, but to all types of FDI, both to mergers and acquisitions (brownfield) and ex novo (greenfield). ${ }^{94}$ Article 2.I of the Regulation defines FDI as:

9г This interpretation, however, can be controversial, given the general principle of mutual recognition and its solid case-law support (for example, Judgment of the Court of 9 March 1999, C-212/97, Centros, ECLI:EU:C:I999:I26, or Judgment of the Court of I3 December 2005, C-41I/o3, Sevic, ECLI:EU:C:2005:762, as well as other provisions of the Regulation such as Article I.3 which emphasizes that each Member State decides whether or not to control each FDI.

$9^{2} \quad$ Lundqvist, supra $\mathrm{n}$. II, at 20 and $5^{2}$.

93 See also ELRev (2019) editorial, supra n. 45, at ${ }_{13}^{8 .}$

94 See, among others, Bourgeois \& Malathouni, supra n.5, at ${ }_{17} 6$. See also MEMO accompanying the Regulation: "Foreign direct investment can take two different forms: greenfield, and mergers and acquisitions (M\&As). International greenfield investment typically involves the creation of a new company or establishment or facilities abroad, whereas an international merger or acquisition amounts to transferring the ownership of existing assets to an owner abroad". 
"an investment of any kind by a foreign investor aiming to establish or to maintain lasting and direct links between the foreign investor and the entrepreneur to whom or the undertaking to which the capital is made available in order to carry on an economic activity in a Member State, including investments which enable effective participation in the management or control of a company carrying out an economic activity". Furthermore, this definition and the criteria used in it must be seen as a consolidation of previous case-law. ${ }^{95}$

It does not cover non-direct investments, passive or portfolio financial investments, nor could it do so with the current legal basis of 207 TFEU. ${ }^{6}$ This is very important for two reasons: first, because the EU is also an important actor in this area ${ }^{97}$ and second, because it creates a vacuum that, in a way, puts the new control of FDI at risk by allowing foreign investment to be channelled as not direct to avoid controls, achieving similar strategic-political ends as an FDI.

Temporal scope. The Regulation applies only to FDI subsequent to the entry into force of the Regulation itself, therefore, never to those made before ro April 2org. ${ }^{8}$ In addition, the European Commission, in the MEMO FAQ that accompanies the Regulation, says that the cooperation mechanism will apply from II October 2o20, since this transitional period is necessary for the adjustment of national controls, the establishment of contact points and to secure channels for information exchange. ${ }^{99}$ But then, can this mechanism be applied retroactively to an already completed FDI? The Regulation does not provide further explanations, but the Commission gives guidance again in its MEMO FAQ. It clarifies that: first, when FDI is subject to national control, the cooperation mechanism will be applied if national control allows it (this will not be the most frequent case given that these national controls normally establish ex ante control regimes and not ex post); second, if the FDI is not subject to national control, the maximum period to start the cooperation mechanism will be $\mathbf{5} 5$ months after the FDI has been carried out. ${ }^{\text {Io }}$

\section{(v) Common minimum requirements}

The Regulation also establishes some common requirements for all national controls: transparency, judicial review and non-discrimination between different third countries, in addition to guaranteeing respect for the protection of confidential information. Therefore, national control systems must clearly establish the circumstances that give rise to supervision, the reasons, procedures, deadlines and (judicial) remedies. It is not a great novelty since these

95 CJEU, Judgment of the Court of 12 December 2006 C-446/o4, Test claimant, ECLI:EU:C:20o6:774, para. I8I, or Judgment of the Court of 22 October 2013 , joined cases $\mathrm{C}-105_{5} / \mathbf{1}_{2}$ to $\mathrm{C}-\mathrm{IO}_{7} / \mathrm{I2}$, Staat der Nederlanden v. Essent NV de others, ECLI:EU:C:2013:677, para. 4o. See also above section (B) (II).

$9^{6}$ Non-direct investments are explicitly excluded from the Common Commercial Policy as confirmed by Opinion 2/ı5, ECLI:EU:C:20I7:376, paras. 225-245, especially 227, and the Preamble of the Regulation, para. 9). They are subject to the chapter on the free movement of capital.

97 Eurostat, Statistics Explained: international Investment Position Statistics.

$9^{8}$ Article 7.Io and Preamble, para. 2I, of the Regulation.

99 See also, although less clear, Article i7 of the Regulation.

ıo See especially para. I3 of the MEMO FAQ. 
requirements were already required by the GJEU case-law on capital movement.

\section{(d) Greater legal certainty?}

One might think that the Regulation offers greater legal certainty to existing national mechanisms and to the new ones that are created. Indeed, given that the Lisbon Treaty included FDI in the EU's Common Commercial Policy and that this is an exclusive competence, doubts could be raised about whether States could, after Lisbon, act in this area without authorization from the EU. Although the issue is controversial, given that the powers to maintain order and public security in the States are national powers as recognized by the TEU itself in its article 4.2, this European Regulation eliminates any doubt in this regard, as it can be understood as an empowerment to the Member States. ${ }^{\text {or }}$

Regarding investors, it is difficult to foresee what the effect of the new mechanisms maybe on their legal certainty. On the one hand, the common framework could bring clarity and facilitate coordination and a unified conception, but, on the other hand, by leaving a lot of margin to the Member States and being a very open framework, it may imply greater complexity, additional controls, more actors involved and, therefore, greater uncertainty about whether the investment can be made. Only time will end up telling us which of the two opposite effects will prevail.

\section{(D) CRITICAL ANALYSIS AND CONCLUSIONS}

\section{(I) A Political Turn: The Announcement of a New Era}

The Regulation should be interpreted as a political and conceptual shift towards more defensive and cautious positions regarding FDI. If previously the Commission had been very favourable to FDI, little inclined to promote controls on them and even belligerent against some of those who wanted to establish them at national level, ${ }^{102}$ the Regulation symbolizes, first, an alert call, and second, a certain turn of position.

The European Union, and the Commission in particular, seem determined to make more differences in the analysis of EU and non-EU investments: remain strict in supervising and stopping restrictions on the former, and, instead, promote greater controls and caution regarding the second, in which it acknowledges that it has been somewhat naive. Although the Regulation focuses on security and public order, it does so in a broad sense, and it cannot be ignored that its adoption owes much to a context of lack of reciprocity and fair competition from new important investors, especially — although not only - the Chinese.

The intensity of the turn is yet to be determined. That it has occurred is undoubted. The European Union remains in favour of investment liberalization, and continues to see FDI as

го In this sense, Martin-Prat, supran. 13, at 97.

${ }_{\text {Iо2 }}$ See, for instance, Bismuth supra n.63, at Io3-ıо7. See also above section (B) (I). 
positive, but not at any cost or in all sectors and conditions. Although the Regulation has not clearly stated it, there is behind a serious concern not only for defending strategic and security interests but also for unfair competition or the need to guarantee the same level playing field. It is possible to foresee, therefore, the development of new controls at national level, the tightening of some of the existing ones and a greater weight of shared opinions on common risks at European level.

It should also be understood that the Regulation could increase the bargaining power of the European Union in investment agreements with third parties, since it cannot be taken for granted that FDI will remain wide open in Europe with almost no limits as until recently.

\section{(2) A Missed Opportunity for Greater Ambition}

However, the Regulation can be seen at the same time as a missed opportunity to respond to the challenge of lack of reciprocity, unfair competition and the possibility of equipping itself with effective mechanisms to require third States to play with the same rules (level playing field). ${ }^{103} \mathrm{Or}$, in other words, the Regulation can be seen as a partial, only half-hearted response to this challenge.

It appears that based on Article 207 TFEU, the Regulation could have referred not only to public order and security but also explicitly to lack of reciprocity or unfair competition. In fact, 207 TFEU already explicitly refers to trade defence measures, including cases of dumping or subsidies. By analogy it should also be feasible to include the possibility of controlling FDI carried out by foreign public companies, subsidized or with the support of government agencies, public companies or sovereign wealth funds and cases of lack of reciprocity. ${ }^{104}$

It is true that the Regulation, in its art. 4.2 a) already includes a mention to this when saying that "In determining whether a foreign direct investment is likely to affect security or public order, Member States and the Commission may also take into account, in particular: (a) whether the foreign investor is directly or indirectly controlled by the government, including state bodies or armed forces, of a third country, including through ownership structure or significant funding; "However, it is only one of the guiding factors that can be used by Member States or the Commission in their analysis of security and public order. It does not seem to enable control simply because this factor is present if it is not linked to a risk to public order and security. Therefore, it is a partial and unsatisfactory response to this risk and allows very limited action. It does not empower to discipline the third State merely for the existence of unfair competition or lack of reciprocity, as some Member States had requested or was sought by the European Parliament. This absence is especially important since: first, the European

${ }_{103}$ Bismuth, supran. 63, at II2-II4. See also the opinion of Prof. Bronckers, as collected in Lavranos, supran. 75, at II7, referring to the regulation that is "solely limited to national security considerations: the EC should address reciprocity, the real issue and not national security".

${ }^{10} 4$ Bismuth, supran. $6_{3}$, at $13^{-114}$. 
Union cannot always resort to the WTO in these cases either, since the agreement on subsidies is only applicable to goods, and the current European trade protection instruments are also limited in scope; secondly, the European control of State aid does not work either because it only applies to aid granted by EU Member States; and third, it does not seem clear that the Member States can include the lack of reciprocity or unfair competition within the exception of public interest, although the CJEU does not seem to have ruled it out with respect to investors from third States. ${ }^{1{ }^{\circ}}$ Therefore, it is logical to think that the European Union should equip itself with an instrument of trade defence for these scenarios and could have (should) have taken advantage of this occasion to fill the existing gap. From this perspective, the Regulation is a missed opportunity.

(3) A Possibilistic Commitment: Towards Greater Awareness, Effective Protection, Bargaining Power, Unity and Legitimacy

As is often the case in political negotiation and even more so in the field of European integration, the Regulation must be seen as a compromise between very diverse and distant positions: that of those who wished more ambitious measures and those who did not consider it necessary and were even reluctant to establish new controls, to tighten existing ones, and, of course, rejected the creation of a powerful single European instrument. ${ }^{\text {106 }}$

It is therefore a possibilistic solution that seeks to advance controls, facilitate the exchange of positions between the Member States and EU Institutions, promote greater awareness of the externalities of FDI beyond national borders and start to think "European" as well in this ambit. It seeks to move towards more effective protection and an increase in European bargaining power, but by adopting regulations that allow unity in progress, even at the cost of less ambition and leave more room for action to each Member State that remains, formally at least, the one who decides. Harmonization exists, but it is minimal (very minimal) and the power of the European Commission, although probably not negligible in practice, is based on soft mechanisms, without binding vetoes. Not surprisingly, for some like SHAAKE, the result is "still quite loose ... be seen more strategically as taking a position in a debate more than coming down with hard regulations". ${ }^{\text {107 }}$

The risk of possible solutions is that it will lead to suboptimal results, so it is not surprising that other avenues such as the use of other legal base ${ }^{108}$ or enhanced cooperation ${ }^{109}$ have been

${ }^{105}$ Lundqvist, supra n. II, at. 42-43.

${ }^{106}$ The then Trade European Commissioner, Cecilia Malmström, acknowledged that the proposal of the European Commission was the outcome of a balance between Member States who don't want anything at all and those that want something much more ambitious.

${ }^{10} 7$ Shaake, supra n. 5 , at Ioo.

${ }^{10} 8$ Cremona, supra n. 57 and Bismuth, supra n. 63 .

${ }^{\circ} 9$ Lundqvist, supra n. II, develops this possibility, stating that it would be better on the basis of Article 73 TFEU than Article 329 TFEU. 
explored by scholars. The advantage of the possibilistic solution is that it allows us to advance in unity, even with soft means, and to give an opportunity to coordinated action and the growth of common understandings. Unity is important in reducing forum shopping, while avoiding unsupervised, unclogged areas through which undesirable investments can sneak in.

Given the great margin that States have and the soft nature of the power acquired by the Commission, it remains to be seen how the progress will materialize, if it occurs with sufficient unity and if it is effective enough. It is also too early to see if the warning that the Regulation announces increases the bargaining power of the European Union to a significant extent and, therefore, allows it to promote the liberalization of investments with third States. It seems that, on this front, the Regulation has important limitations since the lack of reciprocity and unfair competition have not been included as main reasons, but the change made and the possibility of increasing its scope will undoubtedly have an impact. Only time will tell us the final answer to these unknowns.

\section{(4) Just a First Step? Looking into the Future}

In view of all the above, it is questionable whether the Regulation is not only a first step, a symbolic step representing a turn, but only a first step: if, therefore, a more ambitious reform cannot be expected in the future and if it will be accompanied of other commercial defence measures that contribute to filling the existing loopholes.

Regarding the second question, there is indeed no doubt that the Regulation must be seen as just another piece of a puzzle, of a global response to the new challenges detected by unfair competition at a global level. ${ }^{\text {ro }}$ The debate on a better defense of the strategic interests of the Union, the demand for greater reciprocity and the promotion of a new European industrial policy, is still open and a hot-topic. It is certain that sooner than later we will see proposals for reforms relating to our public procurement markets, competition law (merger control, State aid) and trade defence, other sectoral regulations, greater claims of openness to investments and general access to markets in third countries, both multilaterally and, above all, bilaterally (for example, in the ongoing negotiations for an investment agreement between the European Union and China). The substantive debate is more far-reaching and it will be necessary to pay close attention to the interaction of the different pieces of the puzzle and to the overall effect they will produce. ${ }^{\text {"I }}$

Regarding the first question, everything indicates that it would have been very difficult to reach a more ambitious FDI control solution in the short term. As Neergard says, the European Parliament wanted to be more ambitious, but the divergence of positions and sensitivities of

по Bourgeois \& Malathouni, supra n. 5 , at I87-г9г.

II See, in this regard, European Commission, White Paper on levelling the playing field as regards foreign subsidies, $\mathrm{COM}(2020) 253$ final, now subject to public consultation. 
the Member States made it impossible. ${ }^{\text {.2 }}$ Furthermore, the times for its approval before the end of the legislature were very limited (remember that it was passed in record time) and it seemed urgent to take at least a first step and to send a clear signal.

Will it be possible to be more ambitious in the future? In the near future, and with regard to this specific tool, I don't think so. Let be patient: progress has been achieved that cannot be underestimated and we must wait for the results, the implementation by the Member States and the functioning of the planned cooperation mechanisms that, remember, will not start operating until October II, 2020. It is foreseeable that the mechanism will increase the awareness of the States about the externalities of FDI in other Member States and at the European level, as well as that there will be a soft harmonization of the concept of strategic interests and public security at European level with significant contributions by the European Commission. This is the path that has been chosen (perhaps because it was possible) and now we have to see how it works. In any case, there are still unresolved issues. In a more mediumlong term, and depending on the results obtained, not only in the scope of the Regulation but on other fronts (liberalization of investments with third States, reciprocity, level playing field ...), it is not ruled out that a reform could be explored. For such future reforms, the possibilities and limitations of the chosen legal basis (which we have already widely discussed throughout this contribution) must be kept in mind, as well as the possibilities of alternative bases. The context, both intra-EU and on the global stage, will greatly determine the direction of these reforms. Its evolution is too open to be able to venture more than speculation.

In sum, even if aware of its weaknesses, the progress must not be underestimated. It is time to be constructive in exploiting its maximum potential and, furthermore, do it with a European spirit.

\footnotetext{
${ }^{12}$ Neergard, supra n. 29, at I6 7 .
} 